\title{
The Effect of Emissions on U.S. State Total Factor Productivity Growth
}

\section{NEOPHYTA EMPORA}

University of Cyprus

\author{
THEOFANIS P. MAMUNEAS \\ University of Cyprus *
}

\begin{abstract}
This paper investigates the effect of sulphur dioxide (SO2) and nitrogen oxide (NOx) emissions on the Total Factor Productivity (TFP) growth among 48 contiguous U.S. states, for the period 1965-2002. The relationship between TFP growth and emissions is examined using nonparametric econometric techniques that allow for the estimation of the elasticity of pollution for each state and each period and to account for possible nonlinearities in the data. The results indicate that both pollutants positively affect TFP growth. Moreover this effect is nonlinear. The average output elasticity for all states is 0.005 for SO2 and 0.04 for NOx emissions.
\end{abstract}

Keywords: TFP growth, emissions, semiparametric estimation

JEL Classifications: C14, O13, O40

\section{Introduction}

This paper investigates the effect of sulphur dioxide (SO2) and nitrogen oxide (NOx) emissions on the Total Factor Productivity (TFP) growth among 48 contiguous U.S. states, for the period 1965-2002. To this end a consistently specified production function of general form is defined; emissions are a by-product and enter the production function via their relationship with the polluting inputs used in the production of the output. Based on this production function, the index of Total Factor Productivity (TFP) growth is used as a measure of economic growth. The index of TFP growth is the central concept arising from growth accounting and it is constructed by removing from output growth the effect of the growth of the standard inputs, capital and labor. Two pollutants are employed: sulphur dioxide (SO2) and nitrogen oxides (NOx) emissions. The relationship between TFP growth and emissions is then examined using nonparametric econometric methods. This allows for the estimation of

\footnotetext{
* Thanks to a referee and a co-editor helpful comments and suggestions.

(C) 2011 Neophyta Empora and Theofanis P. Mamuneas. Licensed under the Creative Commons Attribution - Noncommercial 3.0 Licence (http://creativecommons.org/licenses/bync/3.0/. Available at http://rofea.org.
} 
the output elasticity of emissions for each state and each period and accounts for possible nonlinearities in the data.

A number of studies have investigated the relationship between environmental quality and economic growth. Most of the literature has focused on examining the relationship between indicators of environmental degradation (a variety pollutants such as sulphur dioxide, nitrogen oxides, carbon monoxide etc) and per capital income. This is the well known Environmental Kuznets Curve (EKC) literature. There are numerous reviews concerning the Kuznets curve literature. The pioneering empirical work in this literature is the work of Grossman and Krueger (1993, 1995). Most of the empirical studies following the study of Grossman and Krueger confirm the inverted-U relationship between pollution and income (Selden and Song (1994), Ansuategi et al. (1998), List and Gallet (1999), Stern and Common (2001), etc.). However, some of the empirical evidence goes counter to the validity of the EKC hypothesis, mostly depending on the choice of the pollution indicators as well as the method used (see Harbaugh, Levinson and Wilson (2002), List, Millimet and Stengos (2003), Azomahou, Lasney and Van (2006) ). Chimeli \& Braden (2005) try to link total factor productivity with the Environmental Kuznets curve by developing a theoretical model. They find a U-shaped response of environmental quality to variations in TFP. This paper departs from this literature in that the relationship between the environment and economic growth is examined from another perspective; the effect of emissions on growth and not the other way around is investigated. Furthermore, as a measure of economic growth the TFP growth index instead of per capita income is used.

There are three main studies in the empirical "green growth accounting”: Tzouvelekas, Vouvaki and Xepapadeas (2007), Vouvaki and Xepapadeas (2008) and Kalaitzidakis, Mamuneas and Stengos (2008). Tzouvelekas et al (2007) estimate the contribution of CO2 emissions, to the growth of real per capita output. They find that the growth of emissions contributes to the growth of output. By ignoring the growth of emissions, the traditional TFP growth estimates are overestimated. Vouvaki et al (2008) reach to the same conclusions by using energy as an input in the production function. The authors argue that energy, a paid input of production generates the unpaid environmental externality, pollution. They use a given marginal damage factor of $\mathrm{CO} 2$ emissions to measure the unpaid part of energy created during the production process. However, the results from both papers are based on this arbitrary marginal damage cost of CO2 emissions. Kalaitzidakis et al (2008) estimate the contribution of CO2 emissions on TFP growth for a set of OECD countries for the years 1981-1998. Their work is conceptually similar to the task undertaken by Tzouvelekas et al (2007). The difference is that they estimate a general production function and their estimates are based on nonparametric methods. They find that the emission stock contributes on average about $1 \%$ to productivity growth for the period under investigation. This paper uses the same approach as in Kalaitzidakis et al (2008) but for two local pollutants NOx and SO2 


\section{EMPORA, MAMUNEAS Emissions and Productivity Growth}

and for the U.S. states instead of OECD countries. U.S. states, unlike various countries, are more comparable in terms of nonenvironmental and environmental data. Different countries differ on various grounds so it is hard to attribute any differences in productivity to emissions. Therefore unlike previous studies the data used here provide a more consistent data set for productivity analysis.

Although the literature on the relationship between pollution and economic growth is extensive, it ignores the role of emissions in the production process. Proper modelling of emissions must take into account the materials balance condition which further results in the intuitively desirable positive correlation between the production residuals and output. To this end this study models the relationship between output and emissions in a manner that is consistent with the residual generation mechanism. It is important to emphasize that the measure of output used to construct the growth variable is gross output. Most-if not all-studies use value added output, when estimating the relationship between output and various pollutants; a look at the pollution generating mechanism (where emissions are a by-product) implies that the correct measure of output to be used is gross output and not value added output.

Summarizing, the contribution of this paper is that apart from a few papers dealing with emissions in the context of growth accounting for a set of OECD or EU countries, there is no estimated relationship between the environment and TFP growth, based on appropriate modelling, correctly constructed variables and a flexible estimation method for the U.S. states. More precisely, emissions are a by-product and enter the production function via their relationship with the polluting inputs used in the production of the output. Two pollutants are used; $\mathrm{NOx}$ and $\mathrm{SO} 2$ emissions. In turn two different measures of these pollutants are employed; emissions (measured in tons) and emission density (or emissions per area emissions divided by the size of a state). For the empirical investigation of the relationship between emissions and economic growth the method of green growth accounting, is employed. The TFP growth index is constructed using the methodology that was adopted in Mamuneas et al (2006). The relationship of the production residuals (emissions) with the U.S. state-level TFP growth is then examined. The nonparametric estimation method used allows for estimating the pattern of the effect of emissions on TFP growth without imposing any restrictive functional form assumptions.

In general, emissions can affect growth in two ways. Emissions can positively affect growth through its connection with the inputs (polluting inputs) used in the production process (positive productivity effect) . Emissions can also have a negative effect on growth since they also represent a negative externality in the production process through the deterioration of environmental quality. For example, emissions can harm the health of productive agents in the economy and deteriorate natural recourses resulting in bad quality inputs or outputs (materials, fishing industries, agriculture crops) . Under these perspectives, 
emissions can positively or negatively affect growth, or both. This study estimates the overall effect; the results confirm the intuitively desirable positive association between emissions and growth. For both SO2 and NOx, the output elasticities of the two measures of emissions (emissions and emission density) are positive for all levels of emissions (and emission density). Moreover, the estimated relationship indicates that this effect is nonlinear.

The paper is organized as follows. The next section presents the model specification, the estimation method and the data. Section 3 discusses the empirical findings and section 4 offers concluding remarks.

\section{Methodology}

\subsection{Model}

Pollution, is modelled either as an input (see, e.g. Baumol and Oates (1988)) or as an (another) output of the production process (see e.g. Fare, Grosskopf and Pasurka (2001)). Modelling pollution as an output captures the idea that "good" output cannot be produced unless pollution ("bad output”) is also produced (see e.g., Fare, Grosskopf, Lovell, and Yaisawarng (1993), Ball, Lovell, Nehring, and Somwaru (1994), and Fernandez, Koop \& Steel (2005)). That is pollution is a by-product of the production of goods. Those who model pollution as an input argue that trying to reduce pollution involves diverting some of the traditional inputs into the abatement effort, something that results in fewer inputs available in the production of goods. In other words it is argued that by reducing pollution, output is reduced and in this sense pollution can be treated as an input into production (see, e.g., Laffont (1988), Cropper and Oates (1992), Koop (1998) and Reinhard, Lovell, and Thijssen (1999)). Another argument in favor of the use of pollution as an input is that pollution represents the extractive use of natural environment. That is pollution is treated as a proxy for the use of environmental resources (see Bovenberg and Smulders (1995), Brock and Taylor (2005)).

A number of authors argue that some of these approaches are inconsistent with the materials balance condition a “...fundamental imperative of physical science-as well as common sense” (Murty \& Russell (2002), p. 16). The materials balance approach was first introduced by Ayres \& Kneese (1969), and it was only recently that has gained attention in the modeling of emissions or production residuals in the production process (Murty \& Russell (2002), Pethig (2003, 2006), Førsund (2009), Lauwers (2009)). The materials balance condition implies that the generation of residuals inevitably arises in the process of consumption and production 1. Murty and Russell (2002) account for this condition by defining a residual generating mechanism that relates the generation of production residuals

\footnotetext{
${ }^{1}$ This paper is confined only to the production side of the economy.
} 
with the use of polluting inputs. These polluting inputs (or material inputs as defined by others like Pethig $(2003,2006)$ ) are used in the production of the output but are also responsible for the generation of a by-product; pollution. Therefore the link between output and pollution comes through the use of the polluting generating inputs.

This study uses the pollution generating mechanism as the main tool used in order for a production function to be defined. A firm or industry or state produces output $y$, using a vector of non residual generating inputs $\mathrm{x}$, and an input vector xe which represents one or more residual generating inputs. Following Murty \& Russell (2002) and Førsund (2009) emissions are modelled as a by-product of the production process. The production of output as well as the generation of the production residual are summarized in the following two equations:

$$
y=F\left(x, x_{e}, t\right)
$$

where $t$ is a technology index measured by time trend. The residual-generation mechanism is described by

$$
e=g\left(x_{e}, t\right)
$$

Solving (2.1.2) for $\mathrm{x}_{\mathrm{e}}, x_{e}=h(e, t)$, and replacing it in (2.1.1) the following production function is defined2 3 :

$$
y=F(x, h(e, t), t)=f(x, e, t)
$$

That is output, $y$, depends on $x$, a vector of traditional inputs like physical capital, $k$, and labor $l$, emissions, $e$ (or production residual) and the time trend t. Having defined the role of emissions in the production process, the next step would be to define a functional form for the production function. Unlike most previous studies the analysis here is based on a general

\footnotetext{
2 The function $g($.) must be monotonic otherwise is not invertible. The 2nd law of thermodynamics implies that: $\frac{\partial e}{\partial x_{e}}=g^{\prime}()>$.0 . So the assumption that $g($.$) is a monotonic function is a reasonable one.$

${ }^{3} x_{e}$ is used as an aggregator factor of material and energy (main polluting) inputs. There are difficulties in aggregating especially in the case of polluting inputs. But this assumption is not so restrictive. For example capital is an aggregator of equipment (high tech, low tech), structure and etc. the same is true for labor (skilled, unskilled labor). The same difficulties applying in the aggregation of capital and labor apply also in the aggregation of polluting inputs. There are many studies that aggregate intermediate inputs to form energy and materials. Despite the difficulties and by acknowledging the problems of aggregation this formulation cannot be avoided.
} 
framework; no a priori parametric functional form is assumed for modelling the relationship between emissions and growth.

Total differentiation of (2.1.3) with respect to time and division by y yields the following for state $i$ in year $t$ :

$$
\hat{y}_{i t}=\hat{\mathrm{A}}_{i t}+\varepsilon_{k_{i t}} \hat{k}_{i t}+\varepsilon_{l_{i t}} \hat{l}_{i t}+\varepsilon_{e_{i t}} \hat{e}_{i t}
$$

where $(\wedge)$ denotes a growth rate, $\hat{\mathrm{A}}=(\partial f / \partial t) / y$ is the exogenous rate of technological change and $\varepsilon_{\mathrm{j}}=\partial \ln f / \partial \ln q_{j}, \quad\left(q_{j}=k, l, e\right)$ denotes output elasticity. Subtracting from both sides of equation (2.1.4) the contribution of traditional inputs to the output growth results to

$$
\hat{y}_{i t}-\varepsilon_{k_{i t}} \hat{k}_{i t}-\varepsilon_{l_{i t}} \hat{l}_{i t}=\hat{\mathrm{A}}_{i t}+\varepsilon_{e_{i t}} \hat{e}_{i t}
$$

Assuming a perfectly competitive environment, the output elasticities of labor and physical capital are equal to the observed income shares of labor, $s_{l}$, and physical capital, $s_{k}$. Therefore a TFP index can be define based on the observable data which discretely approximates the left hand side of equation (2.1.5). This index allows for the contribution of each input to differ across state and time and to be dictated by the data. The Tornqvist index of TFP growth for state $i$ in year $t$ is defined as:

$$
T \hat{F} P_{i t}=\hat{y}_{i t}-w_{K_{i t}} \hat{k}_{i t}-w_{L_{i t}} \hat{l}_{i t}
$$

where $w_{k_{i t}}=0.5\left(s_{k_{i t}}+s_{k_{i t-1}}\right)$ and $w_{l_{i t}}=0.5\left(s_{l_{t i t}}+s_{l_{i t-1}}\right)$ are the weighted average income shares of physical capital and labor and $\hat{q}_{i t}=\ln q_{i t}-\ln q_{i t-1}$, $\quad(q=y, k, l)$. This measure of TFP growth contains the components of output growth that cannot be explained by the growth of the traditional inputs ( $\mathrm{k}$ and l). Using equation (2.1.6), equation (2.1.5) can be written as:

$$
T \hat{F} P_{i t}=\hat{\mathrm{A}}_{i t}+\varepsilon_{e_{i t}} \hat{e}_{i t}
$$

The measured TFP growth is decomposed into the two unknowns to be estimated: the exogenous rate of technological change, $\hat{A}$, and the output elasticity of emissions. This last term in equation (2.1.7) is of central importance for this study since it captures the unobserved contribution of emissions to aggregate productivity. Taking into account that the output elasticity of emissions can vary with the level of emissions, results in the following TFP growth equation:

$$
T \hat{F} P_{i t}=\hat{\mathrm{A}}_{i t}+\theta\left(e_{i t}\right) \hat{e}_{i t}
$$




\section{EMPORA, MAMUNEAS Emissions and Productivity Growth}

where $\theta($.$) is the output elasticity of emissions and it is modelled as a general unknown$ function of the level of emissions. The main advantage of this model is that the effect of emissions on growth depends on the level of emissions for each state and time period. Therefore $\theta($.) captures the state-specific effect of emissions.

\subsection{Empirical Analysis}

In order to estimate equation (2.1.8), the exogenous rate of technological change, $\hat{\mathrm{A}}_{i t}$, is expressed as a function of state dummies and a time trend. State specific dummies, Di, capture idiosyncratic exogenous technological change and time trend captures any timerelated exogenous shifts in technology (Mamuneas et al (2006)). The lagged depended variable $\left(T \hat{F} P_{i t-1}\right)$ is also used as a regressor in order to capture possible serial correlation problems and to account for the dynamic nature of TFP growth. The estimation takes into account two pollutants, SO2 and NOx emissions. In turn two measures of emissions are used; emissions (measured in tons) and emission density (emissions divided by the size of a state). Appending an error term, $u_{i t}$, the equation of interest now becomes4:

$$
T \hat{F} P_{i t}=W_{i t}^{T} \beta+\theta\left(e_{i t}\right) \hat{e}_{i t}+u_{i t}
$$

where $W_{i t}^{T}=\left(D_{i}, t, T \hat{F} P_{i t-1}\right)$ and the error term satisfies $E\left(u_{i t} \mid W_{i t}, e_{i t}, \hat{e}_{i t}\right)=0$.

The model in equation (2.2.1) is estimated using semiparametric estimation methods. In this case the output elasticity of emissions is state and time specific. This allows emissions to influence TFP growth for each state and each period and in a nonlinear fashion. The estimation approach adopted here is based on the smooth coefficient semiparametric model. A smooth coefficient semiparametric model is considered to be a useful and flexible specification for studying a general regression relationship with varying coefficients. It is a special form of varying coefficients models and it is based on polynomial regression (see Fan (1992), Fan and Zhang (1999), Li et al (2002), Kourtellos (2003) and Mamuneas, et al (2006)). A semiparametric varying coefficient model imposes no assumption on the functional form of the coefficients, and the coefficients are allowed to vary as smooth functions of other variables. Specifically, varying coefficient models are linear in the regressors but their coefficients are allowed to change smoothly with the value of other variables5. For comparison, a linear parametric model is also estimated. In this case the output elasticity of emissions is constant.

To estimate equation (2.2.1) a panel data set with information on 48 contiguous U.S. states for the years 1965-2002 is employed. The TFP growth index is constructed for each U.S. state

\footnotetext{
${ }^{4} \mathrm{~N}=48$ and $\mathrm{t}=1965, \ldots, 2002$ in the application.

${ }^{5}$ See Li et al (2002) for a detailed description of the method.
} 
using data on gross output, labor and capital by state. It is important to emphasise that the appropriate measure of output used in the calculation of TFP growth is gross output and not value added output. During the production of output, emissions are generated as a by-product because of the use of polluting inputs for the generation of the output. The main polluting inputs are considered to be energy and materials. Thus by definition gross output and not value added output should be used. The data for gross output by state are not available (only value added output is available) so in order to construct these data, the data set of Jorgenson (1990), and Jorgenson and Stiroh, (2000) as well as state-level data for value added output from Bureau of Economic Analysis (BEA) are used. The data set of Jorgenson (1990) and Jorgenson and Stiroh, (2000) contains information, by sector for the U.S., on the value, prices and quantities of: gross output, labor, capital, energy and materials6. The state-level data of the value added output are used in order to construct shares and apportion the U.S. sector data from Jorgenson (1990) and Jorgenson and Stiroh, (2000) to the state level7. Two pollutants are used, sulphur dioxide (SO2) and nitrogen oxide (NOx) emissions, measured in tons, obtained from the U.S. Environmental Protection Agency (EPA)8.

Further details about the construction and sources of the data as well as descriptive statistics for the main variables of interest are provided in the appendix (see table 1 and figures 1 and 2 of the appendix). The TFP growth ranges from 0.99\% (West Virginia) to 2.88\% (Arizona). States with the highest growth of TFP are the states of Arizona, Georgia, Nevada and North Carolina. On average, the states with relative high (positive) emission growth rates are the states North Dakota (for both NOx and SO2), Arkansas (for SO2) and Nevada (for NOx)9.

\section{Empirical Results}

The model in equation (2.2.1) as well as a parametric linear model are estimated and the results between the two models are compared. As far as the nonparametric model is

\footnotetext{
${ }^{6}$ Time period covered: $1960-2005$.

${ }^{7}$ The data on value added output from the BEA cover a time period from 1963-2008. The sample used for the estimation is constraint to post-1965 data. This is because of the necessary growth calculations as well as the lagged values used in estimation procedure that restricts the sample after 1965. Data are also constraint up to the year 2002 due to the availability of the emissions data.

${ }^{8}$ One of the first papers that used this emission data set by state is the paper by List \& Gallet (1999) for the period 1929-1994. SO2 sources are dominated by fossil fuel burning, industry (ore smelting), and volcanic eruptions. The major sources of NOx include fossil fuel burning, lightning, emissions from the biosphere, stratospheric injections, and biomass burning. The fossil fuel sources for both NOx and SO2 are the largest contributor.

${ }^{9}$ The largest producers of SO2 emissions are the states of Ohio, Indiana and Pennsylvania. The smallest producers of SO2 are the states of Vermont, Rhode Island and South Dakota. The largest producers of NOx emissions are the states of Texas, California and Ohio whereas the smallest producers are the sates of Vermont, Rhode Island and Delaware.
} 


\section{EMPORA, MAMUNEAS Emissions and Productivity Growth}

concerned, estimates of the unknown function $\theta$, that measures the output elasticity of emissions for each state and each period, along with estimates of the coefficients in the linear part of the model, are obtained10. Estimation results are presented in figures 1 and 2, and tables 1, 2 and 3. The nonparametric results are based on standard local kernel estimation using the standard Gaussian density as the kernel. The bandwidth is chosen by crossvalidation11.

In order to test that the model that generated the plotted results in the graphs of figures 1 and 2 is linear, a specification test proposed by Li and Wang (1998) is performed. It tests the null hypothesis of a parametric linear specification against a general nonlinear specification. The value of the test statistic is greater than the critical value in all cases and therefore the null of a linear regression model is rejected12. A serial correlation test is also carried on in both the semiparametric and the parametric linear model. Serial correlation can be attributed to functional form misspecification and/or to error dependence. If serial correlation is present in the linear model and not present in the semiparametric one, this is an indication that serial correlation is due to the presence of nonlinear effects that are not captured by the linear specification (see Li and Hsiao (1998) and $\mathrm{Li}$ and Stengos (2003)). The test results indicate that 1st order serial correlation is present (for both $\mathrm{SO} 2$ and NOx) in both specifications. Including the lagged TFP growth among the regressors and re-conducting the test shows that in the case of the linear parametric model the null hypothesis of no (first order) serial correlation is rejected whereas in the semiparametric model this hypothesis cannot be rejected (at 5\% significance level). It seems that the use of lagged TFP growth as a regressor absorbed any serial correlation that might have been present in the data. The presence and persistence of serial correlation in the parametric linear model is an indication that this is probably not due to serially depended errors; instead it can be attributed to nonlinearities that are present in the formulation of the regression function and are ignored if a linear specification is used. The results from these specification tests are consistent with the graphical analysis: the appropriate specification is one that allows for pollution to affect economic growth in a nonlinear manner. Each graph, of figure 1 plots pointwise estimates of the output elasticity of SO2 and NOx emissions, $\theta($.$) , on the vertical axis and emissions on the horizontal axis, along with the$ upper and lower limit of the $95 \%$ confidence interval for these estimates13. The straight line is the estimated parameter of emissions in the parametric linear specification (when $\theta($.) is a

\footnotetext{
${ }^{10}$ From the derivations of the model: $\varepsilon_{y e}=\frac{\partial f}{\partial e} \frac{e}{y}=\varepsilon_{e}=\theta(e)$.

${ }^{11}$ All nonparametric calculations are performed with Gauss.

${ }^{12}$ The p-value value is 0.0001 for SO2 (for both emissions and emission density) and 0.0002 for NOx (for both emissions and emission density).

${ }^{13}$ The 95\% confidence intervals are computed using 199 bootstrap values.
} 
constant). In all diagrams the linear estimate lies outside the 95\% confidence bands; the heterogeneous estimates obtained from nonparametric estimation indicate that the effect on growth is nonlinear. The output elasticities of both $\mathrm{SO} 2$ and NOx emissions are positive for all levels of emissions. These elasticities increase with the level of emissions (for both pollutants). A closer look indicates that as the level of emissions increase, the positive output elasticities increase with an increasing rate. This heterogeneous effect is one of the main advantages of the nonparametric estimation in contrast with parametric estimation where the output elasticity of emissions is constant. The estimated output elasticity from the linear parametric estimation is 0.005 for $\mathrm{SO} 2$ and 0.037 for NOx14.

Figure 1. Output Elasticities of Emissions
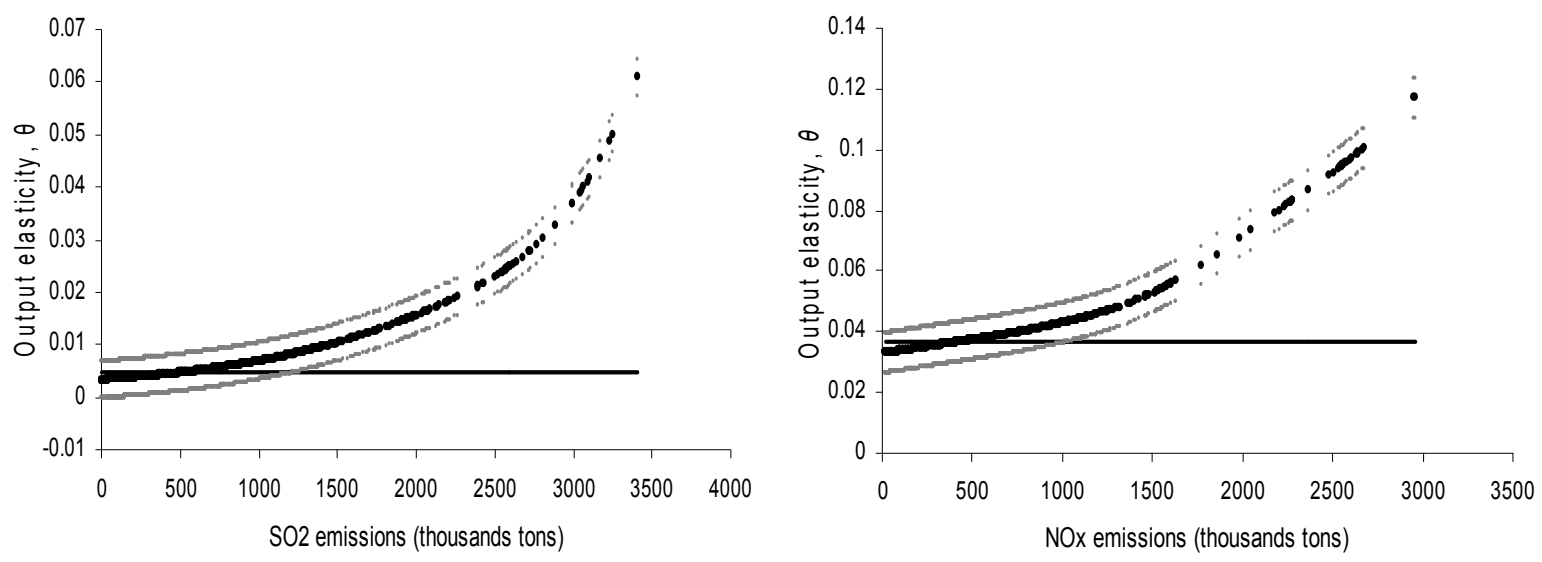

To examine the effect per state, from the nonparametric estimates, the average output elasticities of SO2 and NOx emissions (the $\theta$ 's averaged over years for each state) are presented in table 1 . The average output elasticity of emissions, for all states, is 0.005 for SO2 and 0.04 for NOx. This implies that in the case of SO2, 1\% increase in emissions increases on average output by $0.005 \%$. The average output elasticities of SO2 emissions range from 0.003 (Vermont) to 0.03 (Ohio). In contrast to the very low elasticities for SO2, in the case of NOx, $1 \%$ increase in emissions increases on average output by $0.04 \%$. The average output elasticities of NOx emissions range from 0.03 (Vermont) to 0.09 (Texas). That is, although the pattern of the effect (figure 1) is the same for SO2 and NOx emissions, the magnitude of this effect is different; NOx emissions have, on average, eight times greater estimated output

\footnotetext{
${ }^{14}$ That is $1 \%$ increase in pollution increases on average output by $0.005 \%$ in the case of SO2 and $0.037 \%$ in the case of NOx. The t-statistics are 1.67 and 6.20 for SO2 and NOx respectively.
} 


\section{EMPORA, MAMUNEAS Emissions and Productivity Growth}

elasticity than SO2 emissions. The results are consistent with those in the literature; the intuitively desirable positive association of emissions and growth is found in the empirical analysis15.

Table 1. Output Elasticity of Emissions: Nonparametric Estimates

Average by state, 1965-2002

\begin{tabular}{|c|c|c|c|c|c|}
\hline State & $\mathrm{SO} 2$ & NOx & State & $\mathrm{SO} 2$ & NOx \\
\hline Alabama & 0.00589 & 0.03759 & Nebraska & 0.00340 & 0.03443 \\
\hline Arizona & 0.00761 & 0.03554 & Nevada & 0.00358 & 0.03383 \\
\hline Arkansas & 0.00347 & 0.03491 & New Hampshire & 0.00344 & 0.03340 \\
\hline California & 0.00414 & 0.05306 & New Jersey & 0.00401 & 0.03666 \\
\hline Colorado & 0.00349 & 0.03541 & New Mexico & 0.00400 & 0.03531 \\
\hline Connecticut & 0.00348 & 0.03420 & New York & 0.00619 & 0.04030 \\
\hline Delaware & 0.00337 & 0.03323 & North Carolina & 0.00475 & 0.03795 \\
\hline Florida & 0.00574 & 0.04048 & North Dakota & 0.00363 & 0.03415 \\
\hline Georgia & 0.00566 & 0.03828 & Ohio & 0.02802 & 0.04535 \\
\hline Idaho & 0.00333 & 0.03364 & Oklahoma & 0.00354 & 0.03667 \\
\hline Illinois & 0.01260 & 0.04339 & Oregon & 0.00335 & 0.03464 \\
\hline Indiana & 0.01331 & 0.04082 & Pennsylvania & 0.01226 & 0.04335 \\
\hline Iowa & 0.00400 & 0.03545 & Rhode Island & 0.00328 & 0.03315 \\
\hline Kansas & 0.00362 & 0.03643 & South Carolina & 0.00384 & 0.03533 \\
\hline Kentucky & 0.00707 & 0.03815 & South Dakota & 0.00333 & 0.03348 \\
\hline Louisiana & 0.00420 & 0.04113 & Tennessee & 0.00696 & 0.03816 \\
\hline Maine & 0.00340 & 0.03348 & Texas & 0.00768 & 0.09084 \\
\hline Maryland & 0.00414 & 0.03546 & Utah & 0.00355 & 0.03440 \\
\hline Massachusetts & 0.00407 & 0.0355 & Vermont & 0.00326 & 0.03309 \\
\hline Michigan & 0.00691 & 0.04022 & Virginia & 0.00417 & 0.03695 \\
\hline Minnesota & 0.00375 & 0.03605 & Washington & 0.00366 & 0.03553 \\
\hline Mississippi & 0.00373 & 0.03545 & West Virginia & 0.00727 & 0.03679 \\
\hline Missouri & 0.00673 & 0.03764 & Wisconsin & 0.00483 & 0.0367 \\
\hline Montana & 0.00363 & 0.03400 & Wyoming & 0.00359 & 0.03504 \\
\hline $\begin{array}{l}\text { Average } \\
\text { (all states) }\end{array}$ & 0.00548 & 0.03802 & & & \\
\hline Std. Error & $(0.0047)$ & $(0.0087)$ & & & \\
\hline
\end{tabular}

The 48 contiguous states are included in the data set. The states of Alaska, District of Columbia and Hawaii are excluded from the sample.

${ }^{15}$ In the green growth accounting framework, see Tzouvelekas, Vouvaki and Xepapadeas (2007), Vouvaki and Xepapadeas (2008) and Kalaitzidakis, Mamuneas and Stengos (2008) for estimates for a set of OECD or EU countries and CO2 emissions. Weber and Domazlicky (2001) account for toxic releases and use the directional output distance function in order to measure productivity growth in state manufacturing. Pollution is accounted as another output of the production process. They find that productivity growth is significantly higher when they account for toxic releases relatively to when toxic releases are ignored. 
The above estimations do not account for the size of each state. In order to investigate what happens when the state size is accounted for, emission density (emissions divided by the size of a state) is also used for both pollutants. According to Ansuategi (2003), emissions per area are better measures of environmental impact since the area in which they are released is taken into account. In this way small, high-polluting states are penalized. One could use ambient concentration rates. This paper uses emission divided by the state size and not ambient concentration rates because these two measures, due to the way they are measured, differ in the way they are related to local economic activity. Ambient concentration rates measure the local impact on the environment but ignore the origin of polluting activities; therefore their relationship with local economic activity is not as clear16. On the other hand emissions measure the impact of local polluting activities and therefore are directly related to local economic activity but do not account for the location of the impact of these emissions (Ansuategi, 2003). Dividing emissions by the size of the area in which they are released serves as a good proxy for measuring the environmental effect and thus account for the negative externality effect of emissions17.

Figure 2 plots pointwise estimates of the output elasticity of SO2 and NOx emission density. When emission density is used, the pattern of the effect on growth differs between the two pollutants, SO2 and NOx; as emissions per area increase, the output elasticities increase for SO2 (as in the case of SO2 emissions in figure 1) but decrease for NOx (contrary to the case of NOx emissions in figure 1). While for emissions (figure 1) this is a clear case of emissions being a productive input (through its connection with the polluting inputs used in the production of output) and thus increasing levels are associate with higher output elasticities, the case of emission density is different, at least for NOx. For the case of NOx, when the state size is accounted for, it seems that the negative externality effect increases with increases in emissions density, resulting in reduced output elasticities relatively to lower levels of NOx emission density.

Figure 2. Output elasticities of emission density
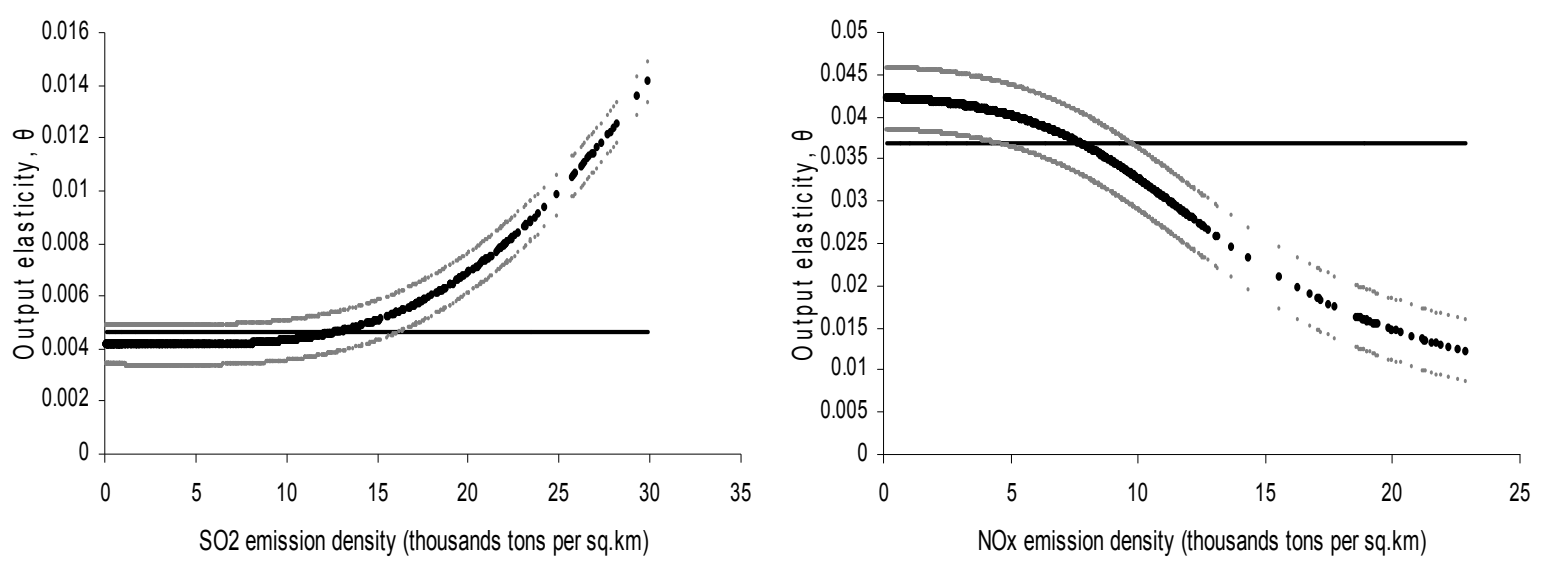
EMPORA, MAMUNEAS Emissions and Productivity Growth

Table 2. Output Elasticity of Emission Density: Nonparametric Estimates

Average by state, 1965-2002

\begin{tabular}{|c|c|c|c|c|c|}
\hline State & $\mathrm{SO} 2$ & $\mathrm{NOx}$ & State & $\mathrm{SO} 2$ & $\mathrm{NOx}$ \\
\hline Alabama & 0.00413 & 0.04085 & Nebraska & 0.00414 & 0.04202 \\
\hline Arizona & 0.00413 & 0.04199 & Nevada & 0.00414 & 0.0421 \\
\hline Arkansas & 0.00414 & 0.04182 & New Hampshire & 0.00412 & 0.04146 \\
\hline California & 0.00414 & 0.04109 & New Jersey & 0.00566 & 0.01575 \\
\hline Colorado & 0.00414 & 0.04198 & New Mexico & 0.00414 & 0.04202 \\
\hline Connecticut & 0.00451 & 0.03008 & New York & 0.00415 & 0.03945 \\
\hline Delaware & 0.00458 & 0.03627 & North Carolina & 0.00412 & 0.04074 \\
\hline Florida & 0.00412 & 0.04019 & North Dakota & 0.00414 & 0.04203 \\
\hline Georgia & 0.00413 & 0.04082 & Ohio & 0.00855 & 0.03254 \\
\hline Idaho & 0.00415 & 0.04210 & Oklahoma & 0.00414 & 0.04161 \\
\hline Illinois & 0.00457 & 0.03793 & Oregon & 0.00415 & 0.04204 \\
\hline Indiana & 0.00662 & 0.03463 & Pennsylvania & 0.00498 & 0.03513 \\
\hline Iowa & 0.00413 & 0.04173 & Rhode Island & 0.00421 & 0.03384 \\
\hline Kansas & 0.00414 & 0.04178 & South Carolina & 0.00412 & 0.04109 \\
\hline Kentucky & 0.00433 & 0.03939 & South Dakota & 0.00415 & 0.04211 \\
\hline Louisiana & 0.00412 & 0.03851 & Tennessee & 0.00429 & 0.03960 \\
\hline Maine & 0.00414 & 0.04204 & Texas & 0.00413 & 0.04110 \\
\hline Maryland & 0.00442 & 0.03366 & Utah & 0.00414 & 0.04203 \\
\hline Massachusetts & 0.00475 & 0.02988 & Vermont & 0.00414 & 0.04196 \\
\hline Michigan & 0.00413 & 0.04130 & Virginia & 0.00412 & 0.04066 \\
\hline Minnesota & 0.00414 & 0.04186 & Washington & 0.00414 & 0.04184 \\
\hline Mississippi & 0.00413 & 0.04161 & West Virginia & 0.00589 & 0.03750 \\
\hline Missouri & 0.00413 & 0.04137 & Wisconsin & 0.00412 & 0.04155 \\
\hline Montana & 0.00414 & 0.04211 & Wyoming & 0.00414 & 0.04200 \\
\hline $\begin{array}{l}\text { Average } \\
\text { (all states) }\end{array}$ & 0.00442 & 0.03932 & & & \\
\hline Std. Error & $(0.0010)$ & $(0.0049)$ & & & \\
\hline
\end{tabular}

The 48 contiguous states are included in the data set. The states of Alaska, District of Columbia and Hawaii are excluded from the sample.

The average output elasticity of emission density, presented in table 2, is 0.004 for SO2 and 0.04 for NOx. These are very close to the average (all states) output elasticity of emissions. The average output elasticities of SO2 emission density range from 0.004 (New Hampshire) to 0.008 (Ohio). In the case of NOx emission density, the elasticities range from 0.02 (New Jersey) to 0.04 (Montana). The average elasticities (for each state) are lower from the ones in the case of emissions. This is also true for the estimated point elasticities in the sample. This indicates that when accounting for the size of the state, the negative externality effect (effect on the environment) might have increased relatively to the positive productivity effect, thereby reducing the overall positive effect. 
The linear parametric estimates for emissions per area are the same with the ones for emissions since the growth rate of the two measures is identical. Unlike the nonparametric model where $\theta$ is a function that depends on the level of emissions and emission density, $\theta(e)$ and $\theta(e /$ size $)$ respectively, and therefore two different effects on growth can be obtained, in the linear parametric estimation $\theta$ is a constant. Therefore in the linear parametric model the estimates between the two measures cannot be distinguished.

Summarizing, comparing SO2 and NOx emissions with $\mathrm{SO} 2$ and NOx emission densities, the range of the estimated output elasticities is lower when the area in which emissions are released is accounted for. This is probably due to the increased negative externality effect. Then comparing the pattern of the effect between the two pollutants for the same measure, SO2 emission density with NOx emission density, it seems that for SO2 the state size doesn't matter whereas for NOx it does matter since the output elasticities decrease when emissions per area increase18.

But for both SO2 and NOx, when emission density is used, the ranking of the states as far as their effect on growth is concerned, changes relatively to when using emission levels. Table 3, reports the ten states with the highest and lowest average output elasticities, for both pollutants and measures. In the case of SO2, the states on the upper tail of figure 1 are more or less the same with the states on the upper tail of figure 2. But some important additions enter into the picture as it can be seen in table 3. When using SO2 emission density, the small, but high polluting relative to their size, states of New Jersey, Massachusetts, Maryland, Delaware and Connecticut enter the picture among the states with the highest emission density levels and with the highest output elasticities. Ohio and Indiana are the biggest producers of SO2 emissions (and remain the biggest relative to their size) and have the biggest estimated output elasticities.

In the case of NOx, contrary to SO2, using emissions per area "penalizes" small but high polluting states. For example New Jersey and Massachusetts (among the smallest U.S. states and among the "low to middle" polluters of NOx emissions) become now the biggest polluters relatively to their size. And their ranking as far as the effect on growth, changes; New Jersey and Massachusetts have the lowest effect on growth while states like Montana and South Dakota (states with the lowest emissions relative to their size) have the biggest, on average (and point estimates), output elasticity.

\footnotetext{
${ }^{18}$ All this information is lost if a linear parametric estimation is employed.
} 
EMPORA, MAMUNEAS Emissions and Productivity Growth

Table 3. Ranking of States as far as the Average Magnitude of Their Estimated Output Elasticities

\begin{tabular}{llll}
\hline Emissions & & \multicolumn{2}{c}{ Emissions per square km } \\
SO2 & NOx & SO2 & NOx \\
\cline { 2 - 3 } & \multicolumn{2}{c}{ States with the highest output elasticity* } \\
Ohio & Texas & Ohio & Montana \\
Indiana & California & Indiana & South Dakota \\
Illinois & Ohio & West Virginia & Nevada \\
Pennsylvania & Illinois & New Jersey & Idaho \\
Texas & Pennsylvania & Pennsylvania & Oregon \\
Arizona & Louisiana & Massachusetts & Maine \\
West Virginia & Indiana & Delaware & Utah \\
Kentucky & Florida & Illinois & North Dakota \\
Tennessee & New York & Connecticut & New Mexico \\
Michigan & Michigan & Maryland & Nebraska
\end{tabular}

States with the lowest output elasticity**

\begin{tabular}{|c|c|c|c|}
\hline Vermont & Vermont & New Hampshire & New Jersey \\
\hline Rhode Island & Rhode Island & South Carolina & Massachusetts \\
\hline Idaho & Delaware & Virginia & Connecticut \\
\hline South Dakota & New Hampshire & Louisiana & Ohio \\
\hline \multicolumn{4}{|c|}{ Table 3 (continued) } \\
\hline \multicolumn{2}{|l|}{ Emissions } & \multicolumn{2}{|c|}{ Emissions per square km } \\
\hline SO2 & NOx & $\mathrm{SO} 2$ & NOx \\
\hline
\end{tabular}

States with the lowest output elasticity**

\begin{tabular}{|c|c|c|c|}
\hline Oregon & Maine & North Carolina & Maryland \\
\hline Delaware & South Dakota & Wisconsin & Rhode Island \\
\hline Maine & Idaho & Florida & Indiana \\
\hline Nebraska & Nevada & Mississippi & Pennsylvania \\
\hline New Hampshire & Montana & Iowa & Delaware \\
\hline Arkansas & North Dakota & Georgia & West Virginia \\
\hline
\end{tabular}


Review of Economic Analysis 3 (2011) 149-172

\section{Conclusion}

Using a consistent model which accounts for the materials balance condition, this paper examines the relationship between U.S. states' emissions (SO2 and NOx) and TFP growth. Estimates of the relationship are obtained using a semiparametric smooth coefficient model. According to the estimates, the output elasticity of emissions is positive for all level of emissions (and emission density) and for both pollutants, SO2 and NOx. On average, the output elasticity of emissions and emission density is the same (for both pollutants); 0.005 for SO2 and 0.04 for NOx. By comparing SO2 and NOx emissions with SO2 and NOx emission densities, the range of the point estimates of output elasticities is lower when the area in which emissions are released is accounted for. This is probably due to the increased negative externality effect when accounting for the environmental impact of emissions. The pattern of the effect is one where the output elasticities increase (nonlinearly) with the level of emissions, except for NOx emission density. Comparing the pattern of the effect between the two pollutants when the state size is taken into account, it seems that for SO2 the state size doesn't matter whereas for NOx it does matter since in the latter case the output elasticities decrease when emissions per area increase. Finally, for both SO2 and NOx, when emission density is used, the ranking of the states, as far as their effect on growth is concerned, changes relatively to when using emission levels. So, accounting for the state size is important since it differentiates the effect between the two pollutants. Any policy regarding emissions should take this into account and be differentiated for different pollutants.

\section{References}

Ansuategi, A., Barbier, E., Perrings, C. (1998), The Environmental Kuznets Curve, in van den Bergh, J.C.J.M., Hofkes, M.W. (eds.), Theory and Implementation of Sustainable Development Modelling, Kluwer Academic, Dordrecht.

Ansuategi A. (2003), Economic growth and transboundary pollution in Europe: an empirical analysis, Environmental and Resource Economics, 26, 305-328.

Ayres, R.U., Kneese. A.V. (1969), Production, Consumption, and Externalities, American Economic Review, 59, 282-97.

Azomahou, T., Laisney, F., Nguyen Van, P. (2006), Economic development and $\mathrm{CO}_{2}$ emissions: a nonparametric panel approach, Journal of Public Economics, 90, 1347-1363.

Ball, V. E., C. A. K. Lovell, Nehring, R. F., Somwaru, A. (1994), Incorporating Undesirable Outputs into Models of Production: An Application to US Agricultural, Cahiers d'Economique et Sociologie Rurales, 31, 59-73.

Baumol, W.J., Oates, W.E. (1988), The theory of environmental policy, Second Edition, Cambridge, England, Cambridge U. Press. 


\section{EMPORA, MAMUNEAS Emissions and Productivity Growth}

Bovenberg, A.L., Smulders, S. (1995), Environmental quality and pollution augmenting technological change in a two-sector endogenous growth model, Journal of Public Economics, 57, 369-391.

Brock, W., Taylor, M.S. (2005), Economic growth and the environment: A Review of Theory and Empirics, in Aghion, P., Durlauf, S. (eds.), Handbook of Economic Growth II, Chap. 28, Elsevier, 1749-1821.

Chimeli, A.B., Braden, J.B. (2005), Total factor productivity and the environmental Kuznets curve, Journal of Environmental Economics and Management, 49, 366-380.

Cole, M. (2003), Development, trade and the environment: how robust is the environmental Kuznets curve?, Environment and Development Economics, 8, 557-80.

Cropper, M. L., Oates W.E. (1992), Environmental Economics: A survey, Journal of Economic Literature, 30, 675-740.

Dasgupta, S., Laplante, B., Wang, H., Wheeler, D. (2002), Confronting the Environmental Kuznets curve, Journal of Economic Perspectives, 16, 147-68.

Dinda, S. (2004), Environmental Kuznets curve hypothesis: a survey, Ecological Economics, 49, 431-455.

Fan, J. (1992), Design-adaptive nonparametric regression, Journal of the American Statistical Association, 87, 998-1004.

Fan, J., Zhang, W. (1999), Statistical estimation in varying-coefficient models, Annals of Statistics, 27, 1491-1518.

Fare, R., Grosskopf, S., Lovell C.A.K., Yaisawarng S. (1993), Derivation of shadow prices for undesirable outputs: a distance function approach, Review of Economics and Statistics, 75, 375-380.

Fare, R., Grosskopf, S., and Pasurka C. (2001), Accounting for air pollution emissions in measures of state manufacturing productivity growth, Journal of Regional Science, 41, 381- 409.

Fernandez, C., Koop, G., Steel, M. F.J. (2005), Alternative efficiency measures for multipleoutput production, Journal of Econometrics, Elsevier 126, 411-444.

Førsund, F. R. (2009), Good Modelling of Bad Outputs: Pollution and Multiple-Output Production, International Review of Environmental \& Recourse Economics, 3, 1-38.

Gradus, R., Smulders, S. (1993), The trade-off between environmental care and long-term growth: pollution in three prototype growth models, Journal of Economics, 58, 25-51.

Grossman G.M., Krueger, A.B. (1993), Environmental Impacts of a North American Free Trade Agreement, in Garber, P. (ed.), The US-Mexico Free Trade Agreement, Cambridge, MA: MIT Press.

Grossman G.M., Krueger, A.B. (1995), Economic Growth and the Environment, Quarterly Journal of Economics, 110, 353-377. 
Harbaugh, T., W., Levinson A., Wilson, D.,M. (2002), Reexamining the empirical evidence for an environmental Kuznets curve, Review of Economics and Statistics, 84, 541-551.

Jorgenson, D.W. (1990), Productivity and Economic Growth, in Berndt, E. and J. Triplett, (eds) Fifty Years of Economic Measurement, NBER Studies in Income and Wealth 54, Chicago: The University of Chicago Press.

Jorgenson, D. W. Stiroh K.J. (2000), Raising the Speed Limit: U.S. Economic Growth in the Information Age. Brookings Papers on Economic Activity, 1, 125-211.

Kalaitzidakis, P., Mamuneas, T. P. and Stengos, T. (2008), The Contribution of Greenhouse Pollution to Productivity Growth, working Papers 2008-2, Department of Economics, University of Guelph.

Koop G. (1998), Carbon Dioxide emissions and economic growth a structural approach, Journal of Applied Statistics, 25, 489-515.

Kourtellos A. (2003), Modeling parameter heterogeneity in cross-country growth regression models, mimeo, University of Cyprus.

Laffont, J.J. (1988), Fundamentals of Public Economics. Cambridge: MIT Press.

Lauwers, L. (2009), Justifying the incorporation of the materials balance principle into frontier-based eco-efficiency models, Ecological Economics, 68, 1605-1614.

List, J.A. and Gallet, C.A. (1999), The Environmental Kuznets Curve: does one size fit all?, Ecological Economics, 31, 409-423.

Li, Q., Hsiao, C., 1998. Testing Serial Correlation in Semiparametric Panel Data Models. Journal of Econometrics 87, 207-237.

Li, Q., Huang, C., Li, D., Fu, T. (2002), Semiparametric smooth coefficient models. Journal of Business Economics and Statistics, 20, 412-422.

List, J.A., Millimet, D., Stengos, T. (2003), The environmental Kuznets curve: Real progress or misspecified models?, Review of Economics and Statistics, 85, 1038-1047.

Li, D.D., Stengos, T. (2003), Testing serial correlation in semiparametric time series models, Journal of Time Series Analysis, 24, 311-335.

$\mathrm{Li}, \mathrm{Q}$. and S. Wang (1998), A simple consistent bootstrap test for a parametric regression function, Journal of Econometrics, 87, 145-165.

Lucas, R. E. (1988), On the Mechanics of Economic Development, Journal of Monetary Economics, 22, 3-42.

Mamuneas, T.P., Savvides, A., Stengos, T. (2006), Economic development and the return to human capital: a smooth coefficient semiparametric approach, Journal of Applied Econometrics, 21, 111-132.

Margulis, S. (1991), A Guide to Back of the Envelope Estimates of Environmental Damage Costs: An Application to Mexico, mimeo, World Bank.

Murty, S., Russell, R. R. (2002), On modelling pollution-generating technologies, mimeo, Department of Economics, University of California, Riverside. 
Pasurka, C. (2008), Perspectives on Pollution Abatement and Competitiveness: Theory, Data, and Analyses, Review of Environmental Economics and Policy, 2, 194-218.

Pethig, R. (2003), The 'Materials Balance Approach' to Pollution: Its Origin, Implications and Acceptance, Economics Discussion Paper No. 105-03, University of Siegen.

Pethig, R. (2006), Nonlinear Production, Abatement, Pollution and Materials Balance Reconsidered, Journal of Environmental Economics and Management, 51, 185-204.

Reinhard, S., Lovell, C.A.K., Thijssen, G. (1999), Econometric Estimation of Technical and Environmental Efficiency: An Application to Dutch Dairy Farms, American Journal of Agricultural Economics, 81, 44-60.

Selden, T., Song, D. (1994), Environmental quality and development: is there a Kuznets Curve for air pollution emissions?, Journal of Environmental Economics and management, 27, 147-162.

Stern, D.I., Common, M.S. (2001), Is there an environmental Kuznets curve for sulfur?, Journal of Environmental Economics and Management, 41, 162-178.

Tzouvelekas, E., Vouvaki, D, Xepapadeas, A. (2007), Total factor productivity and the environment: a case for green growth accounting, FEEM working Paper No. 38.2007.

U.S. Bureau of Economic Analysis (BEA), Regional Economic Accounts.

U.S. Environmental Protection Agency (EPA) National Air Pollutant Emission Trends and National Emissions Inventory (NEI), Emissions Inventory \& Analysis Group; Air Quality Assessment Division, Office of Air Quality Planning and Standards.

Vouvaki, D., Xepapadeas, A. (2008), Total Factor Productivity Growth when Factors of Production Generate Environmental Externalities, MPRA Paper 10237, University Library of Munich, Germany.

Weber, W. L., Domazlicky B. (2001), Productivity Growth and Pollution in State Manufacturing, Review of Economics and Statistics, 83, 195-199.

Zhang, W., Lee, S.Y., Song, X. (2002), Local polynomial fitting in semivarying coefficient model, Journal of Multivariate Analysis, 82, 166-188.

\section{Appendix}

The sample consists of 48 states for the period 1965-2002 or a total of 1824 observations.

The following data by state are used: gross output, the prices of the inputs, capital (K), labor (L), energy (E) and materials (M), and emissions of SO2 and NOx. All values are in million of current dollars and prices are normalized to 1.0 in 1996.

\section{Gross output, capital, labor, materials and energy by state}

The data for gross output by state are not available (only value added output is available) so in order to construct these data the data set of Jorgenson (1990), and Jorgenson and Stiroh, (2000) as well as state-level data for value added output from Bureau of Economic Analysis 
(BEA) are used. The data set of Jorgenson (1990) and Jorgenson and Stiroh, (2000) contains information, by sector in the U.S, on the value, prices and quantities of: gross output, labor, capital, energy and materials. The data by state are constructed as follows:

Labor: The value of labor by state is constructed by summing (over the sectors) the weighted value of labor for each sector (the value of labor in each U.S. sector is obtained by Jorgenson (1990), and Jorgenson and Stiroh, (2000)). The weight used is the percentage of the GDP by state and sector (value of value added output by state and sector, obtained from BEA) to the national (sum of all states') GDP for that sector.

Capital: The value of capital by state is constructed by summing (over the sectors) the weighted value of capital for each sector (the value of capital in each U.S. sector is obtained by Jorgenson (1990), and Jorgenson and Stiroh, (2000)). The weight used is the percentage of the GDP by state and sector (value of value added output by state and sector, obtained from BEA) to the national (sum of all states') GDP for that sector.

Energy: The value of energy by state is constructed by summing (over the sectors) the weighted value of energy for each sector (the value of energy in each U.S. sector is obtained by Jorgenson (1990), and Jorgenson and Stiroh, (2000)). The weight used is the percentage of the value of capital by state and sector (constructed as above) to the national (sum of all states') value of capital for that sector.

Gross Output: The value of gross output by state is constructed by summing (over the sectors) the weighted value of gross output for each sector (the value of gross output in each U.S. sector is obtained by Jorgenson (1990), and Jorgenson and Stiroh, (2000)). The weight used is the percentage of the value of capital plus the value of labor plus the value of energy by state and sector (constructed as above) to the national (sum of all states') value of capital plus value of labor and energy for that sector.

Materials: The value of materials by state is obtained as the difference between the value of gross output and values of labor, capital and energy by state (constructed above).

Prices: The price of each of the variables (gross output and the inputs labor, capital, energy and materials) by state is constructed by summing (over the sectors) the weighted value of the price for each sector (the price of each variable in each U.S. sector is obtained by Jorgenson (1990), and Jorgenson and Stiroh, (2000)). The weight used is the percentage of the value of each variable by state and sector (constructed as above) to the value of each of the variables by state.

Quantities: The quantities of each of the variables (gross output and the inputs labor, capital, energy and materials) by state, are obtained by dividing the value of each variable by state by its relevant price by state (constructed as above). The quantities are measured in millions of 1996 U.S. \$. The variables in constant 1996 prices are the ones used in the model. 


\section{Emissions and other variables used in the regression}

Emissions: Emissions for two air pollutants are used: Sulphur Dioxide (SO2) and Nitrogen Oxides (NOx). The emissions data by state are measured in tons. These data are obtained from the U.S. Environmental Protection Agency (EPA) National Air Pollutant Emission Trends and National Emissions Inventory (NEI), Emissions Inventory \& Analysis Group; Air Quality Assessment Division, Office of Air Quality Planning and Standards. This data set was first used in List and Gallet (1999).

State size: Source: U.S. Census Bureau, 2000 Census of Population and Housing, Summary Population and Housing Characteristics. Internet link:

http://www.census.gov/compendia/statab/geography_environment/land_and_land_use/. 
Review of Economic Analysis 3 (2011) 149-172

Table 1. Data Averages by State (\%, 1965-2002)

\begin{tabular}{|c|c|c|c|c|c|c|}
\hline \multirow[b]{2}{*}{ State } & \multicolumn{6}{|c|}{ Growth of } \\
\hline & $\begin{array}{c}\text { Gross } \\
\text { Output }\end{array}$ & $\begin{array}{l}\text { Labor } \\
\text { input }\end{array}$ & $\begin{array}{c}\text { Capital } \\
\text { input }\end{array}$ & $\begin{array}{l}\text { Total Factor } \\
\text { Productivity }\end{array}$ & $\begin{array}{c}\text { Emissions } \\
\text { of SO2 }\end{array}$ & $\begin{array}{c}\text { Emissions } \\
\text { of NOx }\end{array}$ \\
\hline Alabama & 3.285 & 1.670 & 4.514 & 1.985 & -0.064 & 1.094 \\
\hline Arizona & 5.409 & 3.961 & 6.489 & 2.877 & -6.957 & 2.521 \\
\hline Arkansas & 3.773 & 2.059 & 4.712 & 2.323 & 4.258 & 1.008 \\
\hline California & 3.577 & 2.084 & 4.898 & 2.013 & -1.877 & 0.464 \\
\hline Colorado & 4.702 & 3.304 & 6.000 & 2.468 & 0.055 & 2.118 \\
\hline Connecticut & 3.027 & 1.598 & 4.665 & 1.756 & -5.228 & -0.754 \\
\hline Delaware & 3.659 & 2.365 & 5.423 & 2.012 & -1.051 & 0.128 \\
\hline Florida & 4.936 & 3.546 & 6.293 & 2.542 & 0.831 & 2.846 \\
\hline Georgia & 4.744 & 3.181 & 6.014 & 2.661 & 2.212 & 2.318 \\
\hline Idaho & 3.884 & 2.231 & 4.843 & 2.308 & -3.995 & 2.040 \\
\hline Illinois & 2.361 & 0.865 & 3.747 & 1.444 & -3.950 & -0.371 \\
\hline Indiana & 2.946 & 1.214 & 4.165 & 1.909 & -1.161 & 0.835 \\
\hline Iowa & 2.834 & 1.041 & 3.752 & 1.876 & -1.635 & 1.113 \\
\hline Kansas & 3.033 & 1.461 & 4.003 & 1.841 & 1.771 & 0.985 \\
\hline Kentucky & 3.046 & 1.431 & 4.245 & 1.887 & -0.666 & 1.096 \\
\hline Louisiana & 2.514 & 1.275 & 3.374 & 1.373 & 1.957 & -0.547 \\
\hline Maine & 3.058 & 1.532 & 4.372 & 1.829 & -1.609 & 1.582 \\
\hline Maryland & 3.379 & 2.006 & 4.880 & 1.810 & -0.101 & 0.444 \\
\hline Massachusetts & 3.077 & 1.611 & 4.555 & 1.783 & -2.397 & 0.027 \\
\hline Michigan & 2.360 & 0.772 & 3.763 & 1.530 & -2.837 & 0.034 \\
\hline Minnesota & 3.540 & 2.013 & 4.707 & 2.073 & -1.483 & 1.860 \\
\hline Mississippi & 3.241 & 1.616 & 4.231 & 1.998 & 1.138 & 1.026 \\
\hline Missouri & 2.841 & 1.255 & 4.123 & 1.737 & -1.504 & 0.886 \\
\hline Montana & 2.304 & 0.831 & 3.397 & 1.365 & -5.253 & 1.656 \\
\hline Nebraska & 2.983 & 1.355 & 4.042 & 1.813 & 1.110 & 1.600 \\
\hline Nevada & 5.576 & 4.255 & 6.988 & 2.659 & -2.887 & 3.745 \\
\hline New Hampshire & 4.420 & 2.936 & 5.898 & 2.520 & 1.285 & 2.089 \\
\hline New Jersey & 2.917 & 1.506 & 4.500 & 1.663 & -4.356 & -0.516 \\
\hline New Mexico & 3.158 & 1.903 & 4.144 & 1.633 & -3.231 & 1.124 \\
\hline New York & 2.089 & 0.675 & 3.592 & 1.224 & -3.051 & -0.698 \\
\hline North Carolina & 4.360 & 2.688 & 5.573 & 2.627 & 1.473 & 1.451 \\
\hline North Dakota & 2.658 & 1.029 & 3.566 & 1.621 & 4.567 & 3.803 \\
\hline Ohio & 2.434 & 0.824 & 3.789 & 1.575 & -1.885 & 0.025 \\
\hline Oklahoma & 3.104 & 1.620 & 4.138 & 1.756 & 0.728 & 1.482 \\
\hline Oregon & 3.898 & 2.271 & 5.139 & 2.278 & -0.791 & 1.477 \\
\hline
\end{tabular}


EMPORA, MAMUNEAS Emissions and Productivity Growth

Table 1 (continued)

\begin{tabular}{|c|c|c|c|c|c|c|}
\hline \multirow[b]{2}{*}{ State } & \multicolumn{6}{|c|}{ Growth of } \\
\hline & $\begin{array}{l}\text { Gross } \\
\text { Output }\end{array}$ & $\begin{array}{l}\text { Labor } \\
\text { input }\end{array}$ & $\begin{array}{c}\text { Capital } \\
\text { input }\end{array}$ & $\begin{array}{l}\text { Total Factor } \\
\text { Productivity }\end{array}$ & $\begin{array}{c}\text { Emissions } \\
\text { of SO2 }\end{array}$ & $\begin{array}{c}\text { Emissions } \\
\text { of NOx }\end{array}$ \\
\hline Pennsylvania & 2.431 & 0.875 & 3.783 & 1.515 & -1.213 & -0.442 \\
\hline Rhode Island & 2.615 & 1.151 & 4.089 & 1.559 & -5.210 & -0.778 \\
\hline South Carolina & 4.305 & 2.667 & 5.552 & 2.561 & 2.195 & 1.899 \\
\hline South Dakota & 3.529 & 1.802 & 4.340 & 2.121 & 0.874 & 1.969 \\
\hline Tennessee & 3.991 & 2.372 & 5.222 & 2.353 & -1.319 & 1.329 \\
\hline Texas & 4.364 & 2.964 & 5.416 & 2.358 & 0.776 & 0.014 \\
\hline Utah & 4.191 & 2.812 & 5.329 & 2.247 & -5.205 & 2.302 \\
\hline Vermont & 3.567 & 2.011 & 4.859 & 2.104 & -0.834 & 1.227 \\
\hline Virginia & 4.132 & 2.640 & 5.468 & 2.278 & 0.242 & 0.869 \\
\hline Washington & 4.065 & 2.532 & 5.381 & 2.277 & -1.847 & 2.091 \\
\hline West Virginia & 1.625 & 0.249 & 2.870 & 0.989 & -0.215 & 1.053 \\
\hline Wisconsin & 3.146 & 1.460 & 4.355 & 1.986 & -2.201 & 0.720 \\
\hline Wyoming & 2.556 & 1.262 & 3.738 & 1.225 & 1.264 & 2.231 \\
\hline Average & 3.409 & 1.891 & 4.645 & 1.965 & -1.027 & 1.135 \\
\hline Std.Dev. & 3.973 & 3.855 & 3.461 & 2.582 & 21.333 & 9.940 \\
\hline
\end{tabular}

The 48 contiguous states are included in the data set. The states of Alaska, Hawaii and the District of Columbia are excluded from the sample. Number of observations: 1824 
Review of Economic Analysis 3 (2011) 149-172

Figure 1. Emission of SO2 and NOX, Averages by State (\%, 1965-2002)

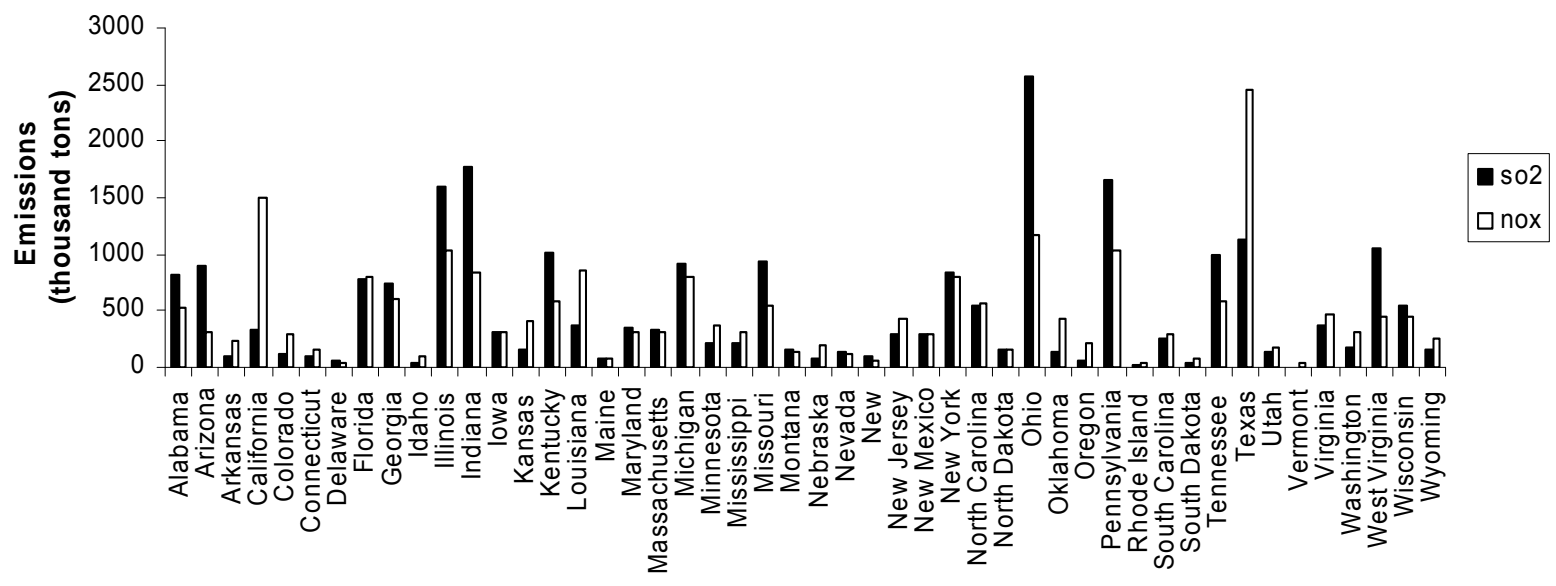

Figure 2. Emission Density of SO2 and NOX, Averages by State (\%, 1965-2002)

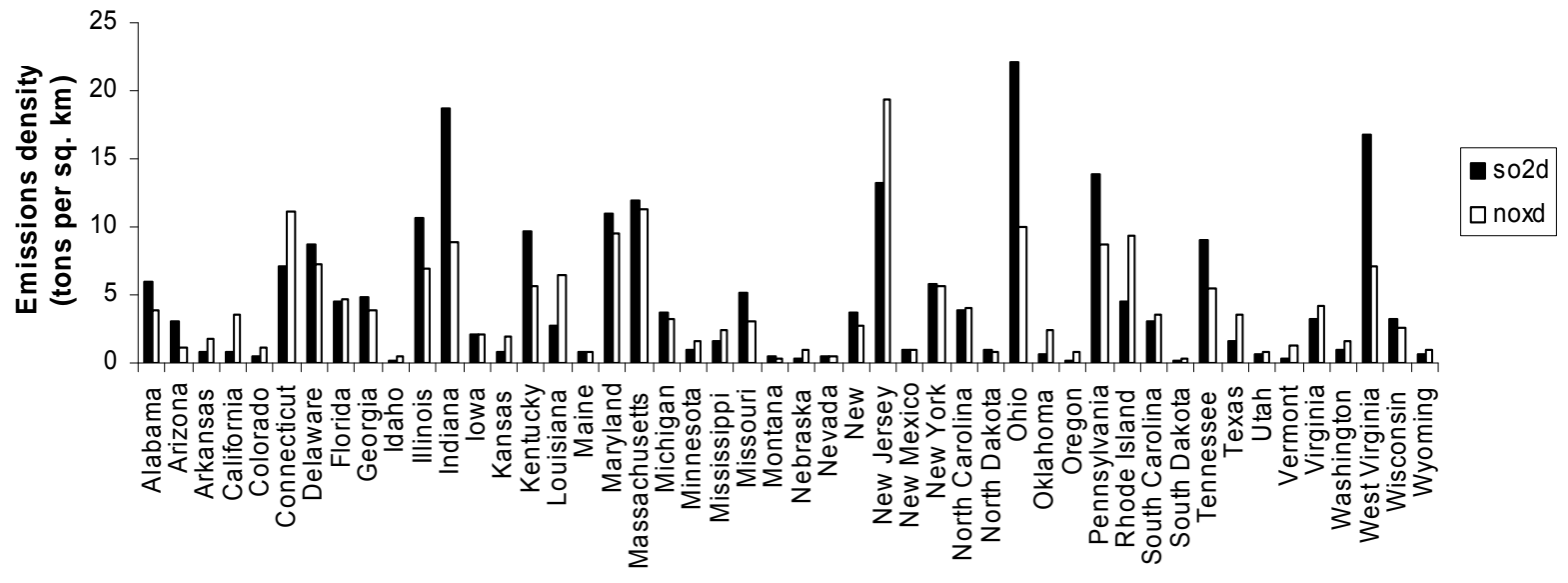

